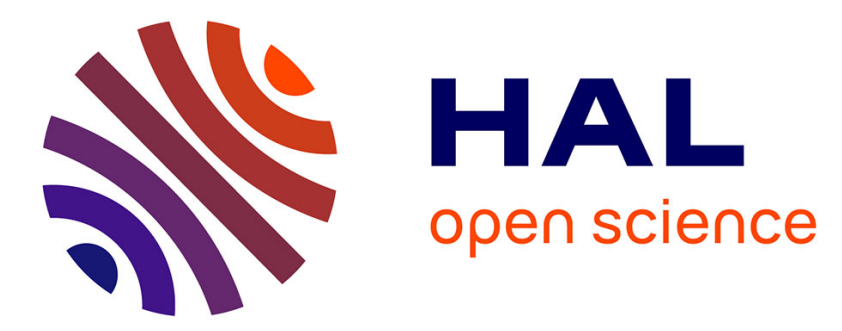

\title{
Influence of low and moderate temperature kiln drying schedules on specific mechanical properties of Norway spruce wood
}

\author{
Laura Oltean, Alfred Teischinger, Christian Hansmann
}

\section{To cite this version:}

Laura Oltean, Alfred Teischinger, Christian Hansmann. Influence of low and moderate temperature kiln drying schedules on specific mechanical properties of Norway spruce wood. European Journal of Wood and Wood Products, 2010, 69 (3), pp.451-457. 10.1007/s00107-010-0467-1 . hal-00615329

\author{
HAL Id: hal-00615329 \\ https://hal.science/hal-00615329
}

Submitted on 19 Aug 2011

HAL is a multi-disciplinary open access archive for the deposit and dissemination of scientific research documents, whether they are published or not. The documents may come from teaching and research institutions in France or abroad, or from public or private research centers.
L'archive ouverte pluridisciplinaire HAL, est destinée au dépôt et à la diffusion de documents scientifiques de niveau recherche, publiés ou non, émanant des établissements d'enseignement et de recherche français ou étrangers, des laboratoires publics ou privés. 


\title{
Influence of low and moderate temperature kiln drying schedules on specific mechanical properties of Norway spruce wood
}

\section{Einfluss niedriger und gemäßigter}

Temperaturen während der technischen

Schnittholztrocknung auf mechanische

\section{Kennwerte von Fichtenholz}

\author{
Laura Oltean ${ }^{1),}$ Alfred Teischinger ${ }^{1), 2)}$ Christian Hansmann ${ }^{2)}$ \\ ${ }^{1)}$ Institute of Wood Science and Technology, Department of Material Sciences and \\ Process Engineering, University of Natural Resources and Applied Life Sciences, \\ Peter Jordan Strasse 82, A-1190, Vienna, Austria \\ ${ }^{2)}$ Wood K plus - Competence Centre for Wood Composites and Wood Chemistry, \\ St.-Peter-Strasse 25, 4021 Linz, Austria \\ "Email corresponding author: laura.oltean@boku.ac.at \\ Article note: preliminary results were presented at ICWSE 2009, Proceedings of the \\ International Conference "Wood science and engineering in the third millennium", \\ Transilvania University of Braşov, România, p.103-110; ISSN 1843-2689
}

\begin{abstract}
The knowledge of the influence of different temperature ranges on mechanical properties of kiln dried timber is very important in structural applications. The current paper deals with an investigation of the influence of low and moderate temperature drying schedules on the selected mechanical properties of Norway spruce wood (Picea abies L.). The drying experiments were performed at four different temperatures $\left(45,55,65\right.$, and $\left.80^{\circ} \mathrm{C}\right)$ and clear wood specimens were prepared for the mechanical tests, three-point bending test, impact bending test, and tensile test perpendicular to the grain, respectively. The results of this systematic investigation were statistically analysed and as a conclusion, it can be stated that the mechanical properties investigated were not influenced by the drying temperatures applied.

Zusammenfassung: Der Einfluss verschiedener Temperaturen auf die mechanischen Kennwerte von technisch getrocknetem Holz ist entscheidend für die konstruktiven Anwendungen. Diese Studie untersucht den Einfluss niedriger und gemäßigter Temperaturen in der Holztrocknung an ausgesuchten mechanischen Kennwerten von Fichtenholz (Picea abies L.). Die Trocknungsversuche wurden bei vier verschiedenen Temperaturen $\left(45,55,65\right.$, und $\left.80^{\circ} \mathrm{C}\right)$ durchgeführt und die mechanischen Kennwerte im Dreipunkt-Biege-, Schlagbiege-, und
\end{abstract}


Querzugversuch an fehlerfreien Proben bestimmt. Das Ergebnis der statistischen Analyse kann keinen Einfluss der angewendeten Trocknungstemperaturen auf die mechanischen Kennwerte nachweisen.

\section{Introduction}

Conventional kiln drying is the most commonly used drying method to systematically remove water from wood and to reach the target moisture content within a reasonable drying time. Most of the kiln driers operate within a specific range of temperature, largely depending on the wood species to be dried and the quality and end use of final products. According to Simpson (1991) the moderate temperature kiln drying regime operates within a temperature range of 43 to $82{ }^{\circ} \mathrm{C}$, whereas a temperature range of 21 to $49{ }^{\circ} \mathrm{C}$ is seen as a low temperature kiln drying regime. While the influence of high temperature drying $\left(>100{ }^{\circ} \mathrm{C}\right)$ on wood properties has been intensively investigated (e.g. Salamon 1969, Schneider 1973, Gerhards 1979, 1983, Sehlstedt-Persson 1995, Källander et al. 2001, Thiam et al. 2002, Bekhta and Niemz 2003, Oltean et al. 2007), only a few investigations have been published about the influence of wood drying on the mechanical properties at a temperature level below $100^{\circ} \mathrm{C}$, such as Teischinger (1992).

During kiln drying of wood, it is generally accepted that most mechanical properties will increase with the decrease in moisture content below fibre saturation point (FSP) and further (Kollmann and Côté 1968, Green et al. 1999, Green 2001). When wood is kiln dried to hygroscopic equilibrium and at a temperature range of 100 to $150{ }^{\circ} \mathrm{C}$, an approximately linear relationship can be considered between drying temperature and mechanical properties of wood (Green et al. 1999). When kiln dried at elevated temperatures the degradation of the wood substance will lead to an irreversible and permanent effect on the wood strength. This loss depends on several factors such as MC, temperature level, heating medium, exposure period, and to some extent, wood species, and size of piece involved. When wood is kiln dried below $100^{\circ} \mathrm{C}$ an immediate and reversible effect can be observed (Green et al. 1999).

Teischinger (1992) studied the effects of different drying temperatures, including conventional drying temperature (between $50-60{ }^{\circ} \mathrm{C}$ ) on spruce wood properties, but none of the mechanical properties investigated showed any changes when compared with air-drying schedules. Both modulus of rupture (MOR) and modulus of elasticity (MOE) values showed no significant changes with the temperature applied as well as the impact bending strength values. In the case of the hardness of Norway spruce wood Hansson and Antti (2006) found out that variables such as density and $\mathrm{MC}$ have a greater influence than does the drying method (conventional or micro-wave drying) or the drying temperature.

Unfortunately, comparisons between the available data from literature are very difficult, due to differences in the experimental designs, such as the selection of the testing materials, the testing methods, the shape and size of the specimens and the experimental conditions.

Following up on a recent study, in which a literature review was undertaken on the influence of the temperature during kiln drying on the occurrence of cracks and on the mechanical properties of solid wood (Oltean et al. 2007), in the present work the influence of the low and moderate temperature kiln drying on the mechanical properties of Norway spruce wood was studied experimentally. A short summary of the results found in the literature concerning 
only the influence of the moderate temperature drying on the mechanical properties of several wood species is shown in Table 1. Due to the fact that most of the studies were performed in the higher temperature range, a systematically investigation is missing from the literature and therefore is necessary to understand and acknowledge the influence of the drying temperature on the mechanical properties of wood in the lower and moderate temperature ranges.

In the present work, Norway spruce wood timber (Picea abies L.) was conventionally kiln dried at low and moderate temperatures from green to $16 \%$ moisture content. Mechanical tests were performed, such as three-point bending, impact bending and tensile tests perpendicular to the grain, in order to investigate the influence of the low and moderate temperature drying on the specified mechanical properties of Norway spruce wood. The hypothesis is that the mechanical properties are influenced by the low and moderate temperature drying schedules.

\section{Materials and methods}

\section{Drying experiments}

Norway spruce (Picea abies L.) wood was provided from an Austrian industrial sawmill. Freshly cut boards with a mean value of the oven-dried density of $415 \mathrm{~kg} / \mathrm{m}^{3}$ (std. dev. $52 \mathrm{~kg} / \mathrm{m}^{3}$ ), presented mixed sapwood and heartwood. The timber dimensions used in these experiments were: length of $700 \mathrm{~mm}$ and four different thicknesses $\mathrm{x}$ width combinations in mm, $25 \times 102,51 \times 102,102 \times 102$, and $102 \times 203$, respectively. After cutting, the boards were sealed on both cross sections with adhesive, in order to prevent drying from the cross sectional ends.

Norway spruce wood boards were dried in a laboratory drying kiln according to the drying schedules summarized in Table 2. For each drying experiment 32 boards (representing all 4 thickness classes, evenly distributed in all drying experiments) were used that have been dried from green to an average moisture content of $16 \%$. Each drying experiment was repeated once. During the drying experiments a constant climate was provided within the chamber, with a constant drying temperature $\left({ }^{\circ} \mathrm{C}\right)$ for each run and an air velocity in the range of 3-4 m/s. The drying temperatures ranged between 45 and $80^{\circ} \mathrm{C}$ and a hygroscopic equilibrium of $2 \%$ was chosen for all experiments. The average drying times of all drying experiments were between 16 and 47 hours (Table 2) depending on the initial moisture content of the freshly cut boards. The severe (hygroscopic equilibrium of $2 \%$ ) drying experiments led to an average final moisture content of $16 \%$, including values from $8 \% \mathrm{MC}$ up to fibre saturation depending on the board thickness. In this way dispersion about the mean could be observed as it occurs also in practice. The final moisture contents are presented in Table 2 for each drying experiment performed as an average of the four board thicknesses.

After drying, all boards were conditioned for several months in a climate chamber (at $\mathrm{T}=20 \pm 3{ }^{\circ} \mathrm{C}$ and $\varphi=65 \pm 2 \%$ relative humidity) until constant moisture content was reached. After reaching uniform moisture content across the whole board thickness (controlled by strip test pieces), defect free specimens were prepared for the selected mechanical properties investigated according to the specified standards. 


\section{Preparation of test specimens}

Norway spruce wood boards (Picea abies L.) were dried according to the schedules described and defect free specimens were produced from the boards for the three-point bending test, impact bending test and for the tensile perpendicular to the grain test. In total, 689 samples were prepared for the mechanical testing, the numbers used for each mechanical test are presented in Table 3. All samples were stored in a climate chamber at a temperature of $20^{\circ} \mathrm{C}$ and a relative humidity of $65 \%$ until constant moisture content was reached.

\section{Mechanical testing}

The chosen mechanical testing, the specified standards which were followed, the number of specimens used for each mechanical test, as well as the devices and some remarks are presented in Table 3. The tensile tests perpendicular to the grain were performed in the radial direction, roughly following the specifications from standard ASTM D 143-83 (1992).

\section{Results and discussion}

The statistical processing of the data obtained is presented in Table 4. It has to be mentioned that the results are presented with respect to the four drying temperatures applied and not according to the eight drying experiments.

For the four drying temperatures applied, mean values were recorded between 76.4 and 82.1 MPa for MOR and from 11.3 to 12.0 GPa for MOE in three-point bending test. Mean values of impact bending strength were recorded between 25.9 and $31.2 \mathrm{~kJ} / \mathrm{m}^{2}$. In the case of tensile tests perpendicular to the grain, mean values of MOR were recorded between 3.9 and $4.0 \mathrm{MPa}$ and of MOE between 142.9 and $161.8 \mathrm{MPa}$.

These values are lower when compared with the values recorded in the standard ÖNORM B 3012 (1998) and fit well with the values presented by Sell (1989). Considering the coefficients of variation they are in accordance with the values stated for Norway spruce wood in ÖNORM B 3012 (1998).

\section{Three-point bending tests}

The influence of the drying schedules applied for Norway spruce wood at low and moderate temperature ranges on MOR and MOE in three-point bending tests are shown in Figure 1 (a) and (b), respectively. Statistical analyses (one way ANOVA) were performed and no significant differences were found (at $5 \%$ significance level) between the drying temperatures applied for MOR and MOE in three-point bending tests. Slightly lower values of MOR were recorded for the drying temperature at $55^{\circ} \mathrm{C}$, and of MOE for the drying temperatures at $55^{\circ} \mathrm{C}$ and $80^{\circ} \mathrm{C}$, but considering the overall results there were no statistical differences between the drying temperatures applied.

These results are in accordance with the results found by Teischinger (1992) where spruce wood was subjected to conventional kiln drying between 50 and $60{ }^{\circ} \mathrm{C}$ and no changes in mechanical properties (MOR and MOE in bending) were found when compared to air-drying schedules. Also Thiam et al. (2002) did not find any significant differences between high-temperature drying $\left(116^{\circ} \mathrm{C}\right)$ and 
conventional drying $\left(82{ }^{\circ} \mathrm{C}\right)$ of western hemlock wood regarding three-point bending tests.

\section{Impact bending strength}

The impact bending strengths of the four drying schedules applied between low and moderate temperature ranges are presented in Figure 2. Slightly greater values were recorded for the $80^{\circ} \mathrm{C}$ temperature drying schedule. However, after the statistical analysis performed, one way ANOVA (at $5 \%$ significance level), no significant differences between the four temperatures applied were found.

In another study performed by Wamming et al. (1999) (Sehlstedt-Persson 2005) spruce wood was dried at a low temperature of $70^{\circ} \mathrm{C}$ and a high temperature of $107^{\circ} \mathrm{C}$ and the impact bending strength was measured. A large variation in toughness was found despite of the well matched samples, with a tendency towards decreased toughness with high temperature drying compared with low temperature drying, but no significant differences were found at $5 \%$ significance level. A greater influence of the material properties of spruce was found, such as density and annual ring width, than the drying method applied. No significant reduction of impact bending strength was also found by Terziev and Daniel (2002) for Scots pine timber regardless if the drying method applied low $\left(20^{\circ} \mathrm{C}\right)$, conventional $\left(60^{\circ} \mathrm{C}\right)$ or high-temperature $\left(115^{\circ} \mathrm{C}\right)$ kiln drying schedules.

\section{Tensile tests perpendicular to the grain}

The relationships between the MOR and MOE values for the tensile test perpendicular to the grain and the drying temperatures applied in the low and moderate temperature ranges are presented in Figure 3 (a) and (b). No significant differences were found at $5 \%$ significance level, between the four drying schedules applied for the MOR and MOE in tensile test perpendicular to the grain.

While strength and stiffness properties of wood provided by the static three-point bending test are the most widely available data sets, tensile strength and stiffness perpendicular to the grain is rarely tested due to the influence of shrinkage checks on its values (Kollmann and Côté 1968). This was the reason why this test was undertaken in this study as it is a more sensitive test in order to reveal a possible influence of the drying defects (e.g. micro cracks) when compared with three-point bending test.

However, it can be noticed from the results of this study that the drying temperatures applied do not have any significant influence on the tensile strength perpendicular to the grain. For defect free samples, the values of tensile stress perpendicular to the grain may only be 2 to $6 \%$ of the values parallel to the grain, which are $45-120 \mathrm{MPa}$ at $12 \%$ moisture content (according to Green 2001).

\section{Conclusion}

As a conclusion it can be stated that the mechanical properties of Norway spruce wood investigated, namely: the three-point bending strength, the impact bending strength, the tensile strength perpendicular to the grain and stiffness values, are not influenced by the low and moderate temperature kiln drying applied. Therefore, the null hypothesis that the mechanical properties of Norway spruce wood are influenced by the drying temperatures applied within the low and moderate ranges of 45 and $55^{\circ} \mathrm{C}$, and 65 and $80^{\circ} \mathrm{C}$, respectively, has to be 
declined. According to the statistical analysis, there are no significant differences (at $5 \%$ significance level) between the drying temperatures applied for the mechanical properties investigated. This information is important in industrial applications that use timber that is conventionally kiln dried at temperatures below $80^{\circ} \mathrm{C}$. Besides the three-point bending tests, also applied in previous studies, the more sensitive test to reveal an impact of temperature in the drying schedule on the mechanical properties of wood, such as tensile test perpendicular to the grain in radial direction, shows no influence of the drying temperature within the low and moderate temperature ranges either.

\section{References}

ASTM D 143-83 (1992) Small clear specimens of timber. Standard Method of Testing

Bekhta P, Niemz P (2003) Effect of high temperature on the change in color, dimensional stability and mechanical properties of Spruce wood. Holzforschung 57:539-546

DIN 52186 (1978) Testing of wood; bending test (Biegeversuch)

DIN 52189 (1981) Testing of wood; determination of impact bending strength

(Schlagbiegeversuch; Bestimmung der Bruchschlagarbeit)

Gerhards CC (1979) Effect of high-temperature drying on tensile strength of Douglas-fir 2 by 4's.

Forest Prod J 29(3):39-46

Gerhards CC (1983) Effect of high-temperature drying on bending strength of yellow-poplar 2 by

4's. Forest Prod J 33(2):61-67

Graham RD (1957) Effect of several drying conditions on strength of coast-type Douglas-fir timbers. Forest Prod J 7(7):228-233

Green DW, Winandy JE, Kretschmann DE (1999) Wood Handbook. Wood as an Engineering material Chap. 4 Mechanical Properties of Wood: pp:1-45

Green DW (2001) Wood: Strength and Stiffness. Encyclopedia of Materials: Science and Technology. ISBN: 0-08-0431526, pp:9732-9736

Hansson J, Antti AL (2006) The effect of drying method and temperature level on the hardness of wood. J Mater Process Tech 171:467-470

Källander B, Bengtsson C, Dahlberg J (2001) Reduction of strength but not stiffness of Norway spruce planks dried at $125^{\circ} \mathrm{C}$ as compared to $70^{\circ} \mathrm{C}$. Proceedings 3rd Workshop on Softwood drying to specific end-uses 11-13 June Helsinki

Kollmann FFP, Côté WA (1968) Principles of Wood Science and technology Part 1. Solid wood. Springer Verlag Berlin Heidelberg New York

Oltean L, Teischinger A, Hansmann C (2007) Influence of temperature on cracking and mechanical properties of wood during wood drying - A review. BioResources 2 (4):789-811 ISSN 1930-2126

ÖNORM B 3012 (1998) Wood species. Characteristics values to terms and symbols of ÖNORM EN 13556 (Holzarten. Kennwerte zu den Benennungen und Kurzzeichen der ÖNORM EN 13556) Salamon M (1965) Effect of high temperature drying on quality and strength of western hemlock. Forest Prod J 15(3):122-126 
EJWWP467_source

Salamon M (1969) High-temperature drying and its effect on wood properties. Forest Prod J 19(3):27-34

Schneider A (1973) Investigations on the convection drying of lumber at extremely high temperatures. Part II: Drying degrade, changes in sorption, colour and strength of pine sapwood and beechwood at drying temperatures from 110 to $180^{\circ} \mathrm{C}$. Holz Roh Werkst 31:198-206 Sell J (1989) Eigenschaften und Kenngrössen von Holzarten. Baufachverlag Dietikon AG Zürich ISBN: 3-85565-223-6 pp:28-34

Sehlstedt-Persson M (1995) High-temperature drying of Scots pine. A comparison between HTand LT-drying. Holz Roh Werkst 53:95-99

Sehlstedt-Persson M (2005) Properties of solid wood. Responses to drying and heat treatment. Licentiate Thesis Luleå University of Technology Department of Skellefteå Campus Division of Wood Science and Technology ISSN: 1402-1757, ISRN: LTU-LIC—05/70—SE

Simpson WT (1991) Dry kiln operator's manual. Chap. 2 Kiln types and features Forest Products Laboratory Agriculture Handbook 198 Madison Wisconsin pp:43-73

Teischinger A (1992) Effect of different drying temperatures on selected physical wood properties. Proceedings 3rd IUFRO international wood drying conference. Vienna. Austria. Aug. 18-21 Terziev N, Daniel G (2002) Industrial kiln drying and its effect on microstructure, impregnation and properties of Scots pine timber impregnated for above ground use. Holzforschung 56:434-439 Thiam M, Milota MR, Leichti RJ (2002) Effect of high-temperature drying on bending and shear strengths of western hemlock lumber. Forest Prod J 52(4):64-68

Thompson WS (1969) Effect of steaming and kiln drying on the properties of Southern pine poles. Forest Prod J 19(1):21-28 
EJWWP467_source

Table 1 Reduction of mechanical properties (in \%) of different wood species influenced by temperature during drying (according to Oltean et al. 2007)

Tabelle 1 Verringerung der mechanischen Eigenschaften (in \%) verschiedener Holzarten unter Einfluss der Trocknungstemperatur (vergleiche Oltean et al. 2007)

\begin{tabular}{|l|c|c|c|c|l|}
\hline Botanical Name & T $\left({ }^{\circ} \mathbf{C}\right)$ & MOR & MOE & CS & Reference \\
\hline Pinus palustris & 83.3 & & 1.6 & 6.1 & Thompson (1969) \\
\hline Pinus sylvestris & 60 & 17.2 & 12.8 & & $\begin{array}{l}\text { Terziev and Daniel } \\
(2002)\end{array}$ \\
\hline Pseudotsuga menziesii & 94 & 3 & 1 & & Graham (1957) \\
\hline Tsuga Canadensis & $71-113$ & 0 -s.i. & & 0-s.i. & Salamon (1965) \\
\hline $\begin{array}{l}\text { Legend: CS-compression strength; MOR-modulus of rupture; MOE-modulus of } \\
\text { elasticity; s.i.-slightly increased }\end{array}$ \\
\hline
\end{tabular}


EJWWP467_source

Table 2 Drying schedules applied for the Norway spruce timber

Tabelle 2 Angewandte Trocknungsprogramme für Fichtenholz

\begin{tabular}{|l|c|c|c|c|c|c|c|c|}
\hline Drying schedule & \multicolumn{2}{|c|}{1} & \multicolumn{2}{c|}{2} & \multicolumn{2}{c|}{3} & \multicolumn{2}{c|}{4} \\
\hline Drying temperature, ${ }^{\circ} \mathrm{C}$ & \multicolumn{2}{|c|}{45} & \multicolumn{2}{c|}{55} & 65 & 80 \\
\hline Drying experiment & 1 & 5 & 2 & 6 & 3 & 7 & 4 & 8 \\
\hline Average final MC, \% & 20 & 16 & 18 & 14 & 17 & 16 & 19 & 16 \\
\hline Drying time, $\mathrm{h}$ & 45 & 47 & 32 & 47 & 25 & 22 & 24 & 16 \\
\hline Hygroscopic equilibrium, \% & \multicolumn{8}{|c|}{$2-4$} \\
\hline Air velocity during drying, m/s & \multicolumn{8}{|c|}{3} \\
\hline
\end{tabular}


EJWWP467_source

Table 3 Details concerning the mechanical tests, the standards followed, number of samples involved for each test and the devices used

Tabelle 3 Details bezüglich der Normprüfungen, Probenanzahl und verwendeten Geräte der mechanischen Untersuchung

\begin{tabular}{|c|c|c|c|l|}
\hline Test & Standards & No. samples & Devices & \multicolumn{1}{|c|}{ Remarks } \\
\hline $\begin{array}{c}\text { Three-point } \\
\text { bending test }\end{array}$ & $\begin{array}{c}\text { DIN 52186 } \\
(1978)\end{array}$ & 190 & $\begin{array}{c}\text { Universal } \\
\text { Testing } \\
\text { Machine } \\
\text { Zwick/Roell } \\
\text { Z100 }\end{array}$ & $\begin{array}{l}\text {-equipped with 2.5 } \\
\mathrm{kN} \text { load cell; } \\
\text { cross-head speed 1 } \\
\mathrm{mm} / \mathrm{min}\end{array}$ \\
\hline $\begin{array}{c}\text { Impact bending } \\
\text { test }\end{array}$ & $\begin{array}{c}\text { DIN 52189 } \\
(1981)\end{array}$ & 256 & $\begin{array}{c}\text { Otto Wolpert } \\
\text { Working } \\
\text { Machine }\end{array}$ & $\begin{array}{l}\text {-equipped with a } \\
15 \mathrm{~kg} \text { hammer }\end{array}$ \\
\hline $\begin{array}{c}\text { Tensile test } \\
\text { perpendicular to } \\
\text { the grain }\end{array}$ & $\begin{array}{c}\text { Roughly } \\
\text { following } \\
\text { ASTM D 143- } \\
83 \text { (1992) }\end{array}$ & 243 & $\begin{array}{c}\text { Universal } \\
\text { Testing } \\
\text { Machine } \\
\text { Zwick/Roell } \\
\text { Z100 }\end{array}$ & $\begin{array}{l}\text {-equipped with 2.5 load cell; } \\
\text { kN loaded until } \\
\text { failure cross-head } \\
\text { speed 1 mm/min }\end{array}$ \\
\hline
\end{tabular}







EJWWP467_source

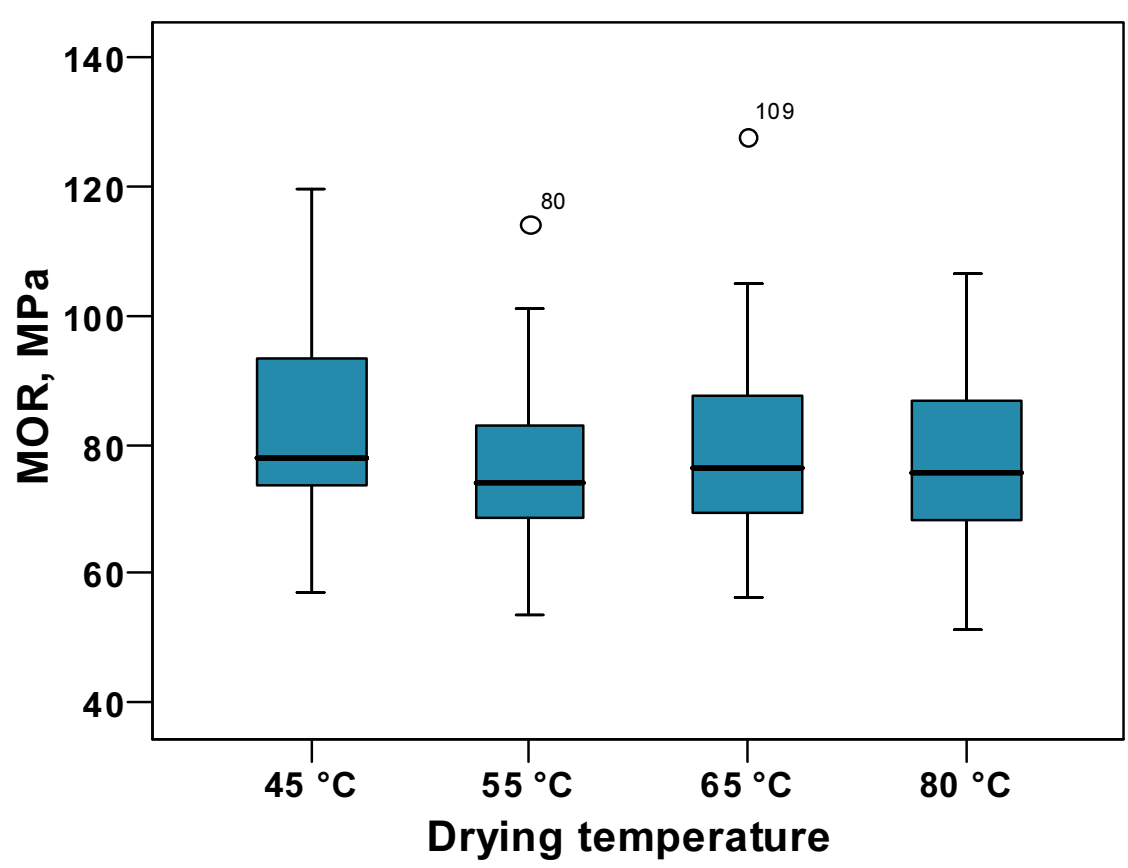

(a)

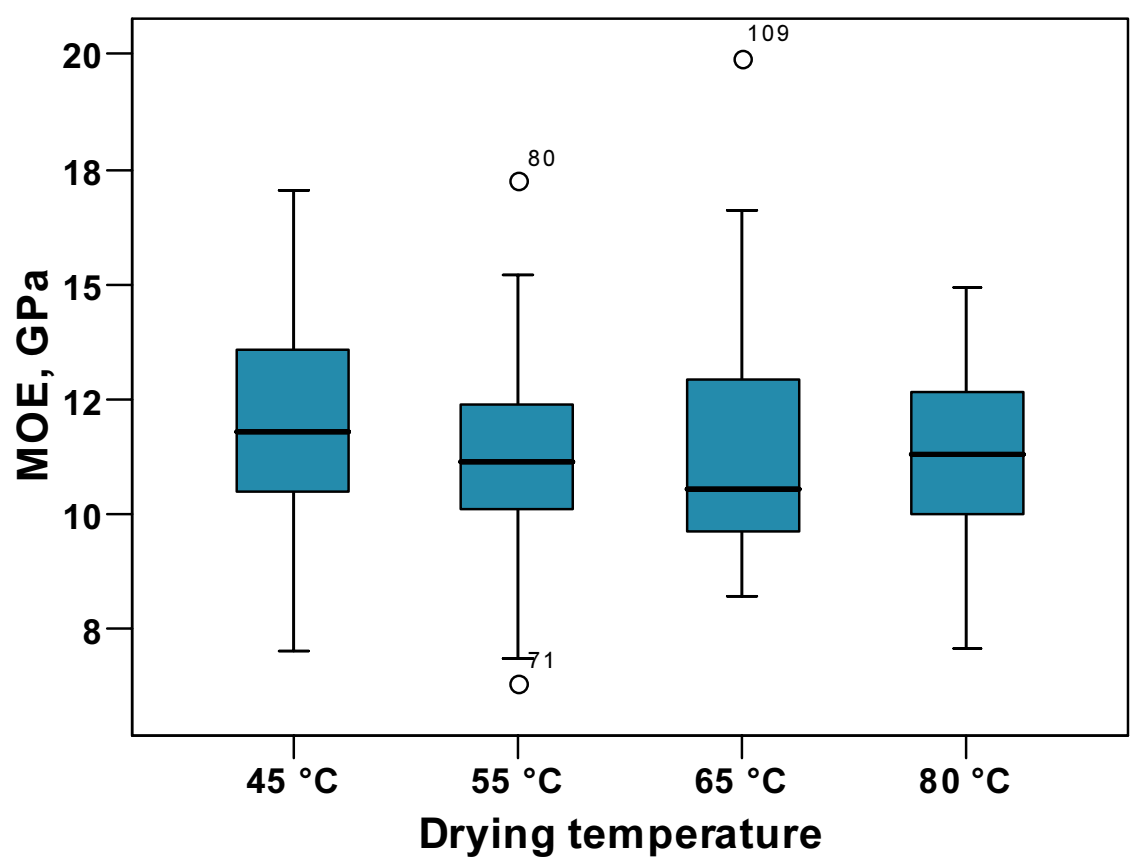

(b)

Fig. 1 Relationship between the drying temperatures and (a) MOR and (b) MOE in three-point bending test. The box represents the median and the 25 - and 75 -percentile, i.e. $50 \%$ of all observed values. The whiskers represent the smallest or the highest values except outliers Abb. 1 Biegefestigkeit (MOR) und Biege-E-Modul (MOE) in Abhängigkeit der Trocknungstemperaturen im Drei-Punkt-Biegeversuch. Der Querbalken in der Box zeigt den Median. Innerhalb der Box liegen die mittleren $50 \%$ aller beobachteten Werte. Die Whiskers begrenzen entweder den kleinsten und größten Wert, sofern sie keine extremen Werte sind 
EJWWP467_source

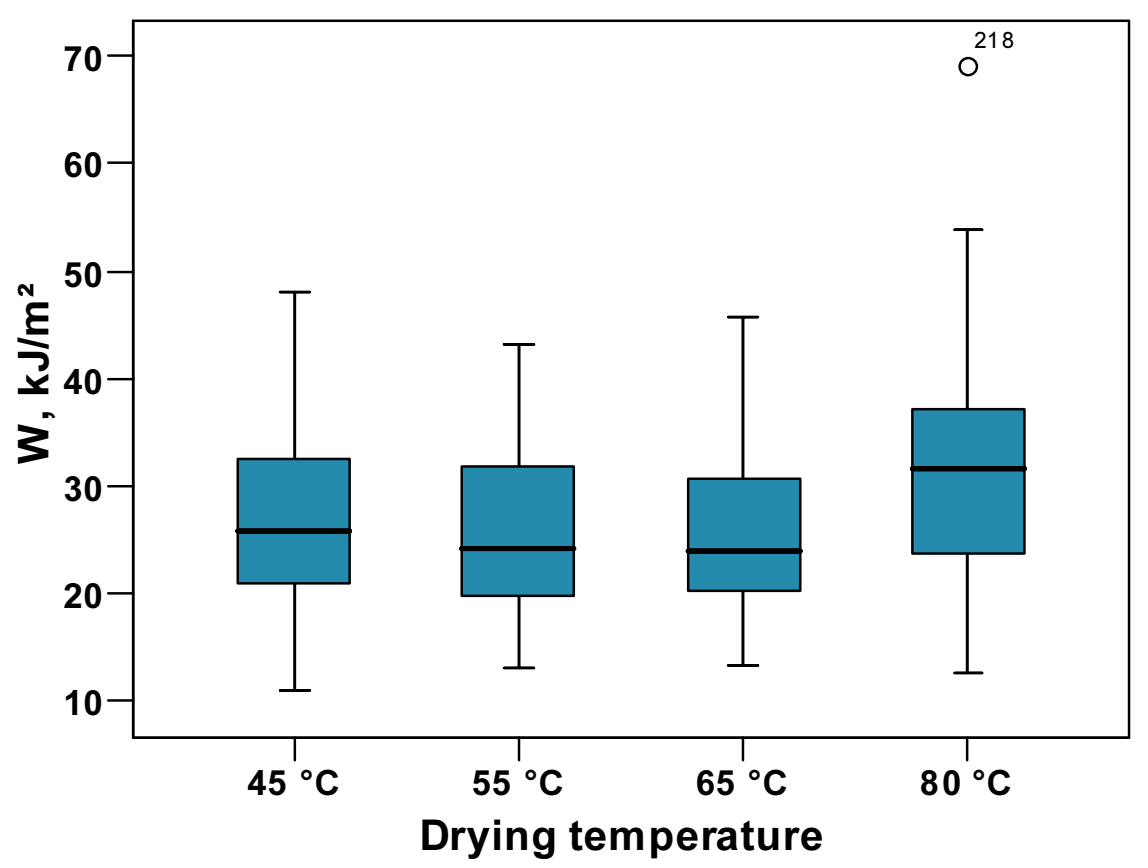

Fig. 2 Relationship between the drying temperatures and the impact bending strength (W). Explanation of box- and whiskers plot see Fig. 1

Abb. 2 Abhängigkeit der Bruchschlagarbeit (W) von den Trocknungstemperaturen. Die Erklärung von Box- and Whiskers siehe Abb.1 
EJWWP467_source


(a)

(b)

Fig. 3 Relationship between the drying temperatures and (a) MOR and (b) MOE in tensile test perpendicular to the grain. Explanation of box- and whiskers plot see Fig. 1

Abb. 3 (a) Querzugfestigkeit (MOR) und (b) E-Modul (MOE) in Abhängigkeit der Trocknungstemperaturen. Die Erklärung von Box- and Whiskers siehe Abb.1 